
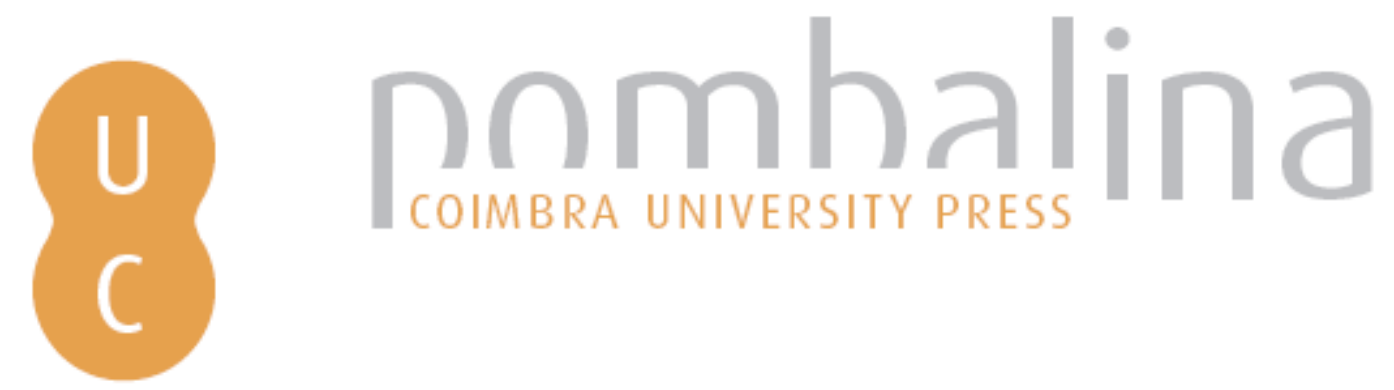

\title{
A historiografia dos descobrimentos portugueses nos séculos XV-XVI e a sua influência sobre o conceito de história em os Lusíadas de Luís de Camões
}

\author{
Autor(es): Ovtcharenko, Olga \\ Publicado por: Imprensa da Universidade de Coimbra \\ URL \\ persistente: URI:http://hdl.handle.net/10316.2/30816 \\ DOI: $\quad$ DOI:http://dx.doi.org/10.14195/978-989-26-0569-2_26 \\ Accessed : $\quad$ 26-Apr-2023 16:26:39
}

A navegação consulta e descarregamento dos títulos inseridos nas Bibliotecas Digitais UC Digitalis, UC Pombalina e UC Impactum, pressupõem a aceitação plena e sem reservas dos Termos e Condições de Uso destas Bibliotecas Digitais, disponíveis em https://digitalis.uc.pt/pt-pt/termos.

Conforme exposto nos referidos Termos e Condições de Uso, o descarregamento de títulos de acesso restrito requer uma licença válida de autorização devendo o utilizador aceder ao(s) documento(s) a partir de um endereço de IP da instituição detentora da supramencionada licença.

Ao utilizador é apenas permitido o descarregamento para uso pessoal, pelo que o emprego do(s) título(s) descarregado(s) para outro fim, designadamente comercial, carece de autorização do respetivo autor ou editor da obra.

Na medida em que todas as obras da UC Digitalis se encontram protegidas pelo Código do Direito de Autor e Direitos Conexos e demais legislação aplicável, toda a cópia, parcial ou total, deste documento, nos casos em que é legalmente admitida, deverá conter ou fazer-se acompanhar por este aviso.

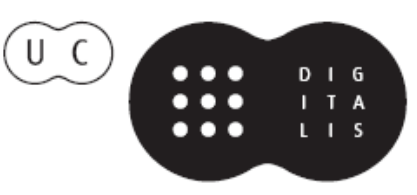




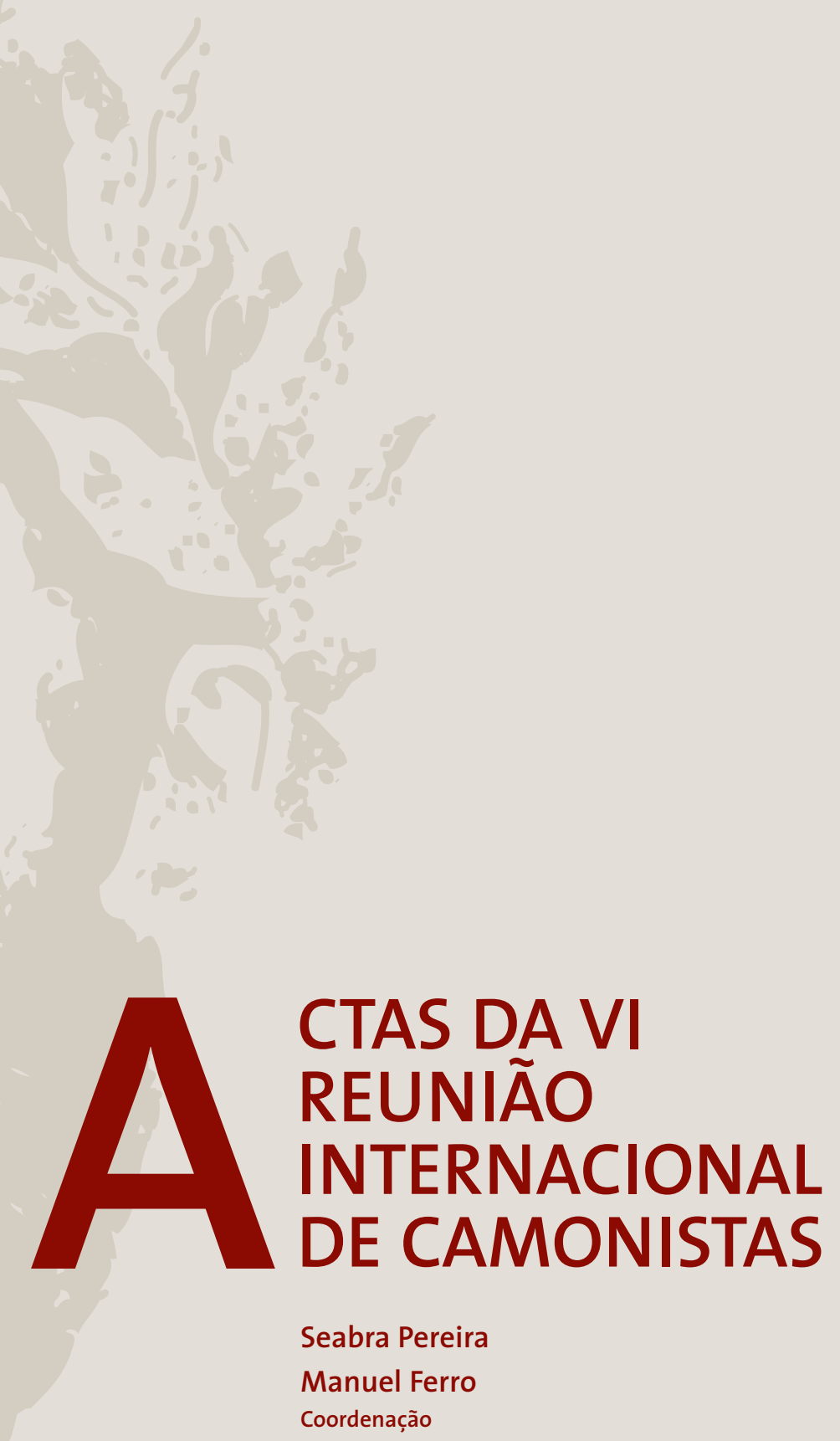


Olga Ovtcharenko

Instituto de Literatura Mundial Gorki / Moscovo

\section{A HISTORIOGRAFIA DOS DESCOBRIMENTOS PORTUGUESES NOS SÉ- CULOS XV-XVI E A SUA INFLUÊNCIA SOBRE O CONCEITO DE HISTÓRIA EM OS LUSÍADAS DE LUÍS DE CAMÓES}

Os Lusíadas, de Luís de Camôes, sendo a mais notável contribuição de literatura portuguesa para a literatura mundial, contudo, não pode ser interpretada como obra excepcional de cultura portuguesa, como um fruto de inspiração de um génio solitário que ficasse à parte das correntes principais de literatura portuguesa. Antes pelo contrário: a nós, parece-nos muito adequada uma ideia do monumento erguido ao príncipe dos poetas portugueses em 1867 em Lisboa, em que a estátua de Luís de Camôes se encontra por cima das de seus antecessores e contemporâneos portugueses: Fernão Lopes, João de Barros, Gomes Eanes de Zurara, Fernão Lopes de Castanheda, Pedro Nunes, e alguns outros.

Realmente, não seria possível conceber Os Lusíadas de Luís de Camões sem a introdução de influência italiana na literatura portuguesa realizada por Francisco Sá de Miranda, sem os estudos linguísticos e o enriquecimento de língua literária portuguesa que se fez através das obras de João de Barros, António Ferreira, Francisco Sá de Miranda e que continuou na obra camoniana. Como se sabe, o material historiográfico usado por Camóes no seu poema épico já foi recolhido por Fernão Lopes, Gomes Eanes de Zurara, Rui de Pina, Fernão Lopes de Castanheda, João de Barros, e muitas vezes o poeta até teve possibilidades de escolher entre interpretaçóes diferentes de factos históricos, sobretudo quando se trata da época dos Descobrimentos portugueses. Até as páginas mais líricas do poema têm as suas analogias em outras obras de literatura ou historiografia portuguesas (pode-se estabelecer paralelos evidentes entre as Trovas que Garcia de Resende fez à morte de D. Inês de Castro e o episódio de Inês de Castro do poema camoniano, ou entre as numerosas digressóes líricas de Luís de Camóes e certas páginas de Zurara, Barros e Castanheda).

O facto de Os Lusíadas serem uma espécie de síntese da literatura renascentista portuguesa é bastante conhecido e não necessita das provas especiais.

Talvez seja mais interessante investigar os elementos de mais valor que Camóes deve aos seus antecessores.

Os lugares paralelos no poema camoniano e nas obras de literatura portuguesa e mundial foram apontados por numerosos estudiosos portugueses e estrangeiros, sendo o sumário provavelmente mais conhecido aquele que foi apresentado numa 
edição popular de Os Lusíadas organizada por Emmanuel Paulo Ramos, publicada pela primeira vez em 1953 no Porto e depois muitas vezes reeditada para uso escolar. Alguns elementos e comentários que o autor fez sobre as fontes da obra-prima camoniana podem parecer discutíveis, mas em geral é um estudo sério baseado sobre o trabalho de várias gerações de investigadores. Emmanuel Paulo Ramos conseguiu encontrar as fontes de quase todos os grandes versos de Os Lusíadas, e contudo a pura existência destas fontes podia não resultar em criação do poema.

Estamos firmemente convencidos de que o elemento de maior importância que Camóes em grande parte deve à historiografia dos Descobrimentos portugueses é a sua visáo da história, a sua óptica dos Descobrimentos portugueses, assim como a opção dos próprios Descobrimentos para a matéria épica; nesse campo se manifestou especialmente o seu génio incomparável.

Resolvendo escrever Os Lusíadas, Camóes logo se colocou no centro da discussão sobre o conceito de verdade, que ocupou a segunda metade do século XV e quase todo o século XVI na literatura portuguesa e que não foi totalmente alheia a outras literaturas renascentistas (pode-se lembrar La Araucana, de Alonso de Ercilla, com sua "la verdad, cortada á su medida" ${ }^{1}$ ).

Já em 1589, generalizando a experiência de historiadores portugueses, Frei Amador Arrais dizia: "Não faltaram Portugueses que tentaram a história de nossos tempos, mas foram alguns deles tão censurados que lhes fora melhor gastar a vida em perpétuo silêncio" 2 . Contudo, sem fazer apologia destes historiadores censurados, acrescenta: "Porque dizer sempre verdades puras sem mistura de respeito, não se sofre: pois passar por elas com ingrato silêncio, ou vender mentiras por certo preço, é fraude infame. Não faltaram alguns que como na vida foram cativos de dinheiro, assim o foram na história. De quem lhe deu muito, disseram muito mais, e nada de quem lhes deu pouco".

$\mathrm{O}$ assunto não era tão simples como o facto de um ou outro historiador ficar "cativo do dinheiro". Ainda Gomes Eanes Zurara, na sua carta ao rei D. Afonso V em relação à Crónica da Guiné, menciona que "aquele que escreve muitos toma por juízes, que entre muitos há desvairamento assim de entender como de vontades... quando passa alguma cousa além do que a eles parece, ligeiramente o julgam por mentira, como estima Salustrio" ${ }^{3}$. Na Crónica do Conde D. Duarte de Meneses, Zurara queixa-se de que "já começam de condenar minha obra. Uns por cuidarem que se dirá menos deles do que lhes sua enganosa afeição faz cuidar que merecem. Outros pensando que quanto se eles mais agravarem de meu escrever tanto o povo haverá razão de cuidar que eles são dignos de maiores merecimentos" 4 .

Mas sabe-se que independentemente destas queixas tanto Zurara, como o seu mecenas $\mathrm{D}$. Afonso $\mathrm{V}$ tiveram uma grande preocupação com a verdade das crónicas. "Vós assaz sois de louvar que com desejo de escrever a verdade do que eles fizeram"

\footnotetext{
${ }^{1}$ Ercilla e Zuñiga, Don Alonso de. La Araucana, Madrid, 1821, Tomo 1, p. 2.

2 Diálogos de D. Frei Amador Arrais, Porto, 1974, p. 222.

${ }^{3}$ Zurara, Gomes Eanes de, Crónica da Guiné, Lisboa, 1973, p. 5.

${ }^{4}$ Zurara, Gomes Eanes de, Crónica do Conde D. Duarte de Meneses, Lisboa, 1978, p. 45.
} 
- escreve o Rei Africano ao seu cronista. - "Vós disposestes a levar o trabalho que eles suportaram" 5 .

Antes de escrever as suas obras, Zurara fazia tudo para recolher as opinióes e memórias dos participantes de acontecimentos (no capítulo I de Crónica de El-Rei D. João I, III parte, até se queixou de que alguns deles "eram tão grandes senhores que pela excelência de seu estado foram sempre tão ocupados que perderam lembrança de mui grão parte de circunstâncias") e ao estudar cuidadosamente os documentos, entendeu que devia conhecer pessoalmente as praças-fortes portuguesas na África de Norte, porque "me convinha haver bom conhecimento per vista de todas aquelas comarcas per que as nossas gentes andaram pelejando com seus imigos"6.

A partir daí, a necessidade de mistura de "honesto estudo" com "longa experiência", de preferência pessoal e ocular, fica quase um lugar comum da literatura dos Descobrimentos portugueses, atingindo o seu apogeu em Fernão Lopes de Castanheda e Fernão Mendes Pinto.

Apesar desta atitude extremamente séria de cronista para com as suas obrigaçóes, não faltam as críticas de interpretação de verdade na sua obra mesmo nos nossos dias. Assim, por exemplo, Álvaro Júlio da Costa Pimpão dizia que "o historiador da vida económica da Nação, na Idade Média, e dos seus reflexos sociais, não encontra, nas crónicas de Zurara, o fundamento das suas teses" e trata-o como "cronista de nobreza" e autor de "uma concepção histórica individualista, mais brilhante do que profunda"7; Óscar Lopes e António José Saraiva acusam-no de "ideologia aristocrática" e "desdém pela gente miúda" 8 . Respondendo a essas acusaçóes, deve-se dizer que o brilho também pode ter profundidade, e o facto de Zurara ter escrito sobre os aristocratas não faz dele, na nossa opinião, um "ideólogo de aristocracia", porque as pessoas como Roland (ou Orlando), Cid Campeador, príncipe Igor, do poema épico russo Palavra sobre expedição militar de Igor, o infante D. Henrique, D. Pedro e D. Duarte de Meneses de certa maneira representam toda a nação e não uma camada social específica. Quanto a mais uma afirmação de Óscar Lopes e A. J. Saraiva, acerca de Zurara ter visto "no infante D. Henrique seu protector a causa única dos Descobrimentos" ${ }^{\text {, }}$, tal parece pouco justa, porque pensamos que as páginas de capítulo V da Crónica da Guinée, "no qual se mostram cinco razóes por que o senhor Infante foi levado a mandar buscar as terras de Guiné" com a sua menção de "inclinação das rodas celestiais"10, fazem parte da colecção das mais bonitas da historiografia portuguesa.

A discussão sobre o conceito de verdade iniciada nos anos 50-60 do século XV nas crónicas de Zurara foi, ou melhor, teve que ser continuada por Fernão Lopes de Castanheda na sua História do Descobrimento e Conquista da Índia pelos portugueses.

5 Ibid., pp. 42-43.

${ }^{6}$ Ibid., p. 47.

${ }^{7}$ Costa Pimpão, Álvaro J. da, História da Literatura Portuguesa - Idade Média, Coimbra, 1959, p. 280.

8 Lopes, Óscar e Saraiva, José, História da Literatura Portuguesa, Porto, 1987, 14a edição, p. 140.

${ }^{9}$ Ibid., p. 140.

${ }^{10}$ Zurara, Gomes Eanes de, Crónica da Guiné, Lisboa, 1973, p. 46. 
Queixando-se à rainha D. Catarina de "alguns vossos Portugueses" que "acanharem-me as obras de meus trabalhos diante de sua alteza", ele insiste na verdade da sua obra: "Se me eu detive vinte tantos anos em escrever esta história, foi porque a fizesse como havia de ser, principalmente na verdade". Esta verdade interpreta-se por ele como resultado de impressóes e experiências pessoais: "a fui saber a Índia passando na viagem braves e terríveis tormentas, com que me vi perto da morte e sem esperança da vida com trabalhos de grande fome e de muito maior sede... E entre elas soube eu a verdade do que havia de escrever" 11 .

Quanto à orientação aristocrática ou democrática de um ou outro cronista, afirma também Castanheda que recolheu algumas informaçóes "não de qualquer pessoas, senão de capitães e fidalgos, pessoas de muito crédito"... Como se sabe, os livros $9^{\circ}$ e $10^{\circ}$ da História de Castanheda não foram impressos por ordem da rainha D. Catarina, e quanto ao $1^{\circ}$ livro, como diz Diogo do Couto, "não deixaram algumas pessoas dignas de fé que el Rey D. João mandara recolher a requerimento de alguns fidalgos que se acharam naquele raro e espantoso cerco, porque falava nele verdade" 12 .

João de Barros, que publicou o $1^{\circ}$ volume das suas Décadas em 1552 , quer dizer um ano a seguir à publicação do primeiro livro da História de Castanheda, teve outra ideia de verdade.

"A primeira e principal parte da história, - escreve ele no Prólogo à sua Década Terceira, - é a verdade dela, e porém em algumas coisas não há de ser tanta... principalmente nas coisas que tratam de infâmia de alguém ainda que verdade sejam"13. O exemplo desta "verdad, cortada a su medida" é para Barros obra de "aquele pintor, que tirando a el-Rey Filipe pai de Alexandre per natural, tomou-lhe a postura do rosto de maneira que lhe encobrisse o defeito que tinha, que era um olho menos" para "notar no Príncipe" nem "os defeitos, em que natureza é culpada", mas "o ánimo dele" 14 . Eis, ao nosso ver, ideia bastante justa e generosa.

Embora nas Décadas se sentisse uma polémica interna com a História de Castanheda, João de Barros tão pouco escapou às críticas de participantes dos acontecimentos descritos e de descendentes, parentes e amigos deles e por isso declarou na Década Quarta, "Apologia de João de Barros em Lugar de Prólogo", que ia desistir da ideia de escrever Europa e África, livros que deviam abranger a história de Portugal a partir de conquista romana até a tomada de Ceuta e passagem dos portugueses pelas terras africanas.

Mas pode-se dizer que quem aproveitou deste plano, no seu poema épico, foi Luís de Camóes.

A crítica moderna de João de Barros assemelha-se muito à de Gomes Eanes de Zurara em que este, aliás com muito respeito, viu o seu antecessor ("do qual nós confessamos tomar a maior parte dos seus fundamentos, por náo roubar o seu a cujo é" ${ }^{15}$ ).

${ }^{11}$ Castanheda, Fernão Lopes de, História do Descobrimento e Conquista da Índia pelos portugueses, Livros I-IV, Porto, 1979, p. 494.

${ }_{12}$ Couto, Diogo do, Década Quarta da Ásia dos Feitos que os Portugueses Fizeram na Conquista e Descobrimento da Terras e Mares do Oriente, Lisboa, 1602, Livro V, cap. I.

13 Barros, João de, Década Terceira da Ásia, Lisboa, 1628, cap. 2.

${ }^{14}$ Ibid., cap. 3.

15 Década Primeira da Ásia de João de Barros, Lisboa, 1628, (A carta do escritor ao rei D. João III). 
Assim, por exemplo, escreve Rodrigues Lapa que "esse orgulho de ser português" se reflecte tendenciosamente, como não podia deixar de ser, na sua afirmação histórica. Essa diferença mais se acusa, se o compararmos ao seu sucessor, Diogo do Couto, homem rijo e bravio, que à custa de mil e uma dificuldades procurou dizer a verdade, não poupando os Portugueses, que iam à Índia "para vindimar durante três anos aquela vinha”, e ainda ao seu contemporâneo Gaspar Correia, que flagela sem piedade os abusos da governaçáo. João de Barros era incapaz dessa rude coragem, pelo seu temperamento, pela sua educaçáo e pela atmosfera em que vivia ${ }^{16}$.

Desta maneira pode-se afirmar que na segunda metade do século XV e no século XVI na historiografia portuguesa formaram-se dois conceitos de verdade. O primeiro, de verdade elevada, verdade generosa, verdade de feitos realizados na terra mas projectados para o céu, pertence a Gomes Eanes de Zurara e João de Barros e tem o seu análogo literário em Os Lusíadas de Luís de Camóes. O segundo, mais ligado ao relatório de factos terra a terra sem procurar nele a realização de alta ideia humana e divina, é mais próprio de Castanheda e Diogo do Couto e tem a sua semelhança literária na Peregrinação de Fernão Mendes Pinto, o que não isola totalmente Camóes da influência de Castanheda, cuja obra conheceu profundamente, e das ideias de Diogo do Couto, de quem foi amigo pessoal.

Tanto Zurara, como Barros, além de conhecer a verdade dos factos em que foram não menos catequizados que Castanheda ou Diogo do Couto (sabe-se que foram entregues a João de Barros duas arcas de papéis de Nuno da Cunha) ${ }^{17}$ têm uma visão global dos Descobrimentos portugueses e do lugar deles na história da sua nação e do mundo. Esta diferença na interpretação da verdade dos factos tem um significado muito moderno. Ainda em 22 de Janeiro de 1929, Máximo Gorki, na sua carta à socialista-revolucionária Iekaterina Kuskóva, que o criticou pelo facto de ficar calado sobre as violências que tiveram lugar na Rússia, disse: "O problema é que de uma maneira mais sincera e inabalável detesto a verdade que a 99 por cento é uma coisa aborrecida e mentirosa... Para mim, têm importância, sobretudo, as coisas seguintes: o crescimento de personalidade do novo homem culto; tem importância um operário de uma fábrica de açúcar que lê Shelley no original; tem importância uma pessoa de interesse largo e saudável para com a vida, a pessoa que compreende que está a construir um estado de novo modelo.

Ele não precisa da verdade mesquinha e maldita entre a qual vive; ele necessita de afirmação daquela verdade que ele próprio está a criar" ${ }^{18}$.

Camóes também muitas vezes insistiu na verdade da sua narração. No canto $\mathrm{V}$ (23), ele afirma que está a cantar "tudo sem mentir, puras verdades", e, como que respondendo ao apelo de Castanheda sobre a necessidade de impressóes pessoais para os que cantam os feitos de portugueses no Oriente, ele sublinha:

${ }^{16}$ Barros, João de, O Descobrimento da Índia. Selecção, prefácio e notas Rodrigues Lapa, Lisboa, 1977, p. 9.

17 Ibid., p. 3.

${ }_{18}$ Kuskóva Ie. D, Tragédia de Máximo Gorki (em russo), Novi Journal, 1954, Vol. 38-39, p. $237-242$. 
"Vi, claramente visto, o lume vivo

Que a maritima gente tem por santo"

$(\mathrm{V}, 18)$

"Os casos vi que os rudos marinheiros,

Que tem por mestra a longa experiência,

Contam por certos sempre e verdadeiros"

$(\mathrm{V}, 17)$

"Eu o vi certamente (e não presumo

Que a vista me enganava): levantar-se

No ar um vaporzinho e sutil fumo..."

$(\mathrm{V}, 19)$

No mesmo canto V, que pode ser chamado um autêntico manifesto de realismo de Camôes, ele diz que:

"Se os antigos Filósofos, que andaram

Tantas terras, por ver segredos delas,

As maravilhas que eu passei, passaram,

A táo diversos ventos dando as velas,

Que grandes escrituras que deixaram!

Que influição de signos e de estrelas!

Que estranhezas, que grandes qualidades!

E tudo sem mentir, puras verdades."

$(\mathrm{V}, 23)$

Mas uma citação mais famosa relacionada com este assunto é, sem dúvida, a seguinte:

"A verdade que eu conto, nua e pura,

Vence toda grandíloqua escritura!"

$(\mathrm{V}, 89)$

Contudo, a verdade que cantou Camóes não é bem nua e pura, e aliás não deveria ser assim num poema heróico-épico. Desde o início, Camóes promete cantar as pessoas que faziam "mais do que prometia a força humana", "as memórias gloriosas" dos reis portugueses, o "alto império" do rei D. Sebastiáo e o "amor da pátria... mas alto e quase eterno", o que subentende "um som alto e sublimado, um estilo grandíloquo e corrente" e "uma fúria grande a sonorosa".

O conceito heróico da história portuguesa e a atribuição a ela do significado providencial tiveram o seu início, sem dúvida nenhuma, nas obras de Zurara e Barros. Gomes Eanes de Zurara viu na vida do Infante D. Henrique um exemplo "não somente para os príncipes que depois de vossa idade possuissem estes Reinos, mas ainda por todolos outros do mundo" 19

19 Zurara, Gomes Eanes de, Crónica da Guiné, Lisboa, 1973, p. 4. 
e na sua idealização chegou a dizer que o seu herói teve "o corpo assim austinado que quase parecia que reformava outra natureza" e que "assim como os poetas fingiram que Atlas o gigante sustinha os ceus com os ombros... assim as gentes do nosso reino traziam em vocábulo que os grandes trabalhos deste Príncipe quebrantavam as altezas dos montes" 20 .

Podem-se encontrar vários exemplos de caracterização parecida dos guerreiros portugueses no canto X de Os Lusíadas, onde Camóes fala de "o grão Pacheco, Aquiles Lusitano", Francisco e Lourenço de Almeida, Martim Afonso de Sousa, "que de Marte o nome tem com as obras derivado", e muitos outros representantes da conquista e da navegação portuguesa no Oriente.

É também em Zurara e Barros que Camóes encontrou a argumentação da necessidade de expansão marítima portuguesa com o fim de "atrair as bárbaras naçôes ao jugo de Cristo" ${ }^{21}$. Contudo, Camóes alarga um tanto este conceito, interpretando os feitos dos portugueses no Oriente como a alta missão civilizacional de Portugal para com os povos bárbaros, relacionada com edificação de "fortalezas, cidades e altos muros" e introdução nestas terras das "leis melhores".

É evidente que Camôes ficou influenciado pelo conceito cavaleiresco da expansão marítima próprio para João de Barros, que, na sua carta a D. João III, interpretou o seu romance Crónica do Imperador Clarimundo como um "debucho... pera esta vossa Ásia”.

Se compararmos o início da História de Castanheda com o conceito de Descobrimentos nas Décadas de João de Barros, vamos descobrir uma diferença séria. Logo nas primeiras linhas de História diz-se o seguinte: "Antes que a Índia fosse descoberta pelos portugueses, a maior parte das especiarias, droga e pedrarias dela se vazava pelo mar Roxo, donde ia ter à cidade de Alexandria, e ali a compravam os venezianos que a espalhavam pela Europa... el-Rey D. Joáo III... determinou de prosseguir o descobrimento de costa da Guiné... para que por ali podesse entrar na Índia, donde por seus capitães podesse mandar levar aquelas riquezas que os Venezianos the iam vender" 22 .

João de Barros vê a sua obra como uma coisa "ordenada de cima" 23 , começa-a pela história da conquista da Península Ibérica pelos mouros e vê o início da época dos Descobrimentos na conquista de Ceuta. Barros compreende a "majestade e grandeza" da sua composição e consegue descobrir conteúdo sublime e generoso em feitos dos descobridores portugueses.

É nele, e não em Castanheda, que se inspirou Camóes no episódio do discurso que Vasco da Gama pronunciou depois de ter recebido do rei D. Manuel a "chave deste cometimento grande e grave", quer dizer da procura do caminho marítimo para a Índia.

${ }^{20}$ Zurara, Gomes Eanes de, Crónica dos Feitos Notáveis que se Passaram na Conquista da Guiné, Lisboa, 1978, p. 28.

${ }^{21}$ Década Primeira da Ásia de João de Barros, Lisboa, 1628, Fol. 13.

${ }^{22}$ Castanheda, Fernáo Lopes de, História do Descobrimento e Conquista da Índia pelos portugueses, Livros I-IV, p. 7-8.

${ }^{23}$ Década Primeira da Ásia de João de Barros, Lisboa, 1628, (Carta ao rei D. João III). 
Também, quanto à descrição da própria partida de Vasco da Gama e das despedidas que os lisboetas lhe fizeram no Restelo, Castanheda é muito parcimonioso nas palavras, dizendo apenas que "ia com eles a maior parte da gente de Lisboa, e a mais dela chorava com piedade dos que iam embarcar, crendo que haviam todos de morrer" 24 , enquanto Barros desenvolve uma imagem sublime e trágica: "Onde feito silêncio, e todos de joelhos, o vigairo de casa fez em voz alta uma confissão geral: e no fim dela os absolveu na forma das bullas que o infante dom Henrique tinha havido para aqueles que neste descobrimento e conquista falecessem. No qual acto foi tanta a lágrima de todos, que neste dia tomou aquela praia posse de muitos que nela se derramam na partida das armadas que cada ano vão a estas partes que Vasco da Gama ia descobrir, donde com razão lhe podemos chamar praia de lágrimas para os que vão e terra do prazer aos que vem" 25 .

É por estas palavras que se inspirou Luís de Camóes nas oitavas 86 a 94 do seu canto IV, o que de maneira nenhuma pode pôr em questão a sua independência criadora. $\mathrm{O}$ escritor genial escreveu variaçóes ao tema do escritor eminente, elevando-as ao mais alto nível do que o próprio tema e ainda continuando-as no episódio tão significativo como o Velho do Restelo, que não tem análogos nem em Barros, nem em Castanheda, embora se possa estabelecer semelhanças com algumas poesias de Sá de Miranda.

Os Lusiadas têm de certa maneira um sabor cavaleiresco e aristocrático próprio para Zurara e João de Barros, mas esta cavalaria tem um carácter mais moral do que social, porque todos os três escritores interpretam os Descobrimentos como a façanha máxima do espírito humano que o aproxima ao Deus. As palavras do Velho do Restelo contêm não só a crítica, mas também a justificação dos Descobrimentos, porque comparam "os segundos argonautas" com Prometeu e Ícaro.

Assim como João de Barros, Camóes vê o início dos Descobrimentos na tomada de Ceuta pelo rei D. João I que "o torpe Mahometa / Deita fora, e segura toda Espanha / Da Juliana, má e desleal manha”. O rei D. João II que enviou para o Oriente os seus emissários Pêro da Covilhã e Afonso de Paiva é representado por ele como pessoa que "mais do que tentar pode homem terreno tentou"... Sobre o rei D. Manuel diz que sucedeu a D. João II "no Reino e nos altivos pensamentos", entre os quais o de "acrescentar a terra cara". O poeta sublinha, sobretudo, não o valor comercial da expedição de Vasco da Gama, mas o grande esforço humano necessário para a sua realização. D. Manuel logo avisa Vasco da Gama que o escolheu para "trabalho ilustre, duro e esclarecido". Muitas vezes Camóes compara os navegadores aos heróis da Antiguidade, pessoas que "dão os corpos... a perigos incógnitos do mundo, a naufrágios, a peixes, ao profundo”.

Esta atitude foi herdada por Camóes de Zurara e, sobretudo, de João de Barros. Zurara, ao indicar as razóes da conquista da Guiné, destaca os factores de grande valor humano, com "magnanimidade deste Príncipe", a procura de "alguma povoação de Cristãos”, a necessidade de divulgação da fé cristã e a já mencionada “inclinação das rodas celestiaes" 26 .

${ }^{24}$ Castanheda, Fernão Lopes de, História do Descobrimento e Conquista da Índia pelos portugueses, Livros I-IV, p. 11.

${ }^{25}$ Década Primeira da Ásia de João de Barros, Lisboa, 1628, Fol. 63.

${ }^{26}$ Zurara, Gomes Eanes de, Crónica da Guiné, Lisboa, 1973, p. 46. 
João de Barros interpreta os Descobrimentos portugueses como uma "alta empresa"27 testada ao rei D. Manuel pelos "príncipes de louvada memória" ${ }^{28}$, e Vasco da Gama jura, assim como em Os Lusíadas, de guardar e defender a Cruz "per tôdolos perigos de água, fogo e ferro" 29 . Os problemas de comércio ocupam nas Décadas de Barros, assim como em Os Lusíadas, um lugar mínimo. Mas é, por exemplo, a João de Barros que Camóes deve a belíssima expressão "se mais mundo houvera, lá chegara" (VII, 14), porque já Barros fala de nação portuguesa como de "ânimo que se tevera criado outros mundos, já la tevera metido outros padróes de vitórias" 30 .

Em geral, se em Castanheda se sente um cronista honesto e, como dizia Diogo do Couto, "diligente", em Barros manifesta-se sobretudo o grande escritor, pessoa de ideias humanistas, historiador que é, de certa maneira, nem menos honesto que Castanheda, mas que, assim como Máximo Gorki e Camóes, sabe que os factos nem sempre reflectem a verdade global dos acontecimentos.

Para provar mais uma vez a maior proximidade de Camóes a Barros (e seu antecessor Zurara) do que a Castanheda, vamos comparar a história de Monçaide nas duas fontes em discussão.

Castanheda (livro I, capítulo XVI) relata as palavras que Monçaide disse aos portugueses e informa que "lhe Vasco da Gama agradeceu muito, prometendo-lhe de o fazer com de muito bem: certificando-lhe que estava o mais ledo homem no mundo em o achar ali e tê-lo de sua parte" ${ }^{31}$.

Barros vê no comportamento de Monçaide significado mais profundo, dizendo que este "da hora que entrou em os navíos assim se fez familiar a Vasco da Gama, que se veu com ele para este reino, onde morreu cristão. $\mathrm{O}$ qual, como esperava acabar neste estado, era táo fiel a nossas coisas que por meio dele foi Vasco da Gama avisado de muitas; e parece que Deus o trouxe àquelas partes para proveito nosso, segundo o que passou, como veremos" 32 .

Estas palavras são mais próximas à visão da actividade de Monçaide em Camóes (canto IX, 15):

"Isto tudo lhe houvera a diligência

De Monçaide fiel, que também leva,

Que, inspirado de Angélica influência

Quer no livro de Cristo que se escreva,

Oh! Ditoso Africano, que a clemência

Divina assim tirou de escura treva,

E tão longe da pátria achou maneira

Para subir à pátria verdadeira.

(IX, 15)

${ }^{27}$ Barros, João de, O Descobrimento da Índia, p. 14.

${ }^{28}$ Ibid., p. 18.

${ }^{29}$ Ibid., p. 20.

${ }^{30}$ Barros, João de, op. cit., p. 94.

${ }^{31}$ Castanheda, Fernão Lopes de, História do Descobrimento e Conquista da Índia pelos portugueses, Livros I-IV, p. 42.

32 Barros, João de, op. cit., p. 94. 
Avaliando as Décadas de João de Barros, Óscar Lopes e António José Saraiva reconhecem nelas "um aspecto positivo e moderno: aquilo a que poderíamos chamar a sua concepção ecuménica da história" ${ }^{3}$. Esta concepção não pode ser atribuída exclusivamente a Barros, sendo produto de todo o pensamento histórico e político português dos séculos XIV e XV. Ainda nas palavras de Zurara, que concebeu a sua Crónica da Guiné como exemplo "por todolos outros do mundo", na carta que o rei D. Afonso V enviou a Zurara para Alcacer-Ceguer, evocando as memórias de Tito Lívio, Homero e Lucano ${ }^{34}$, no facto de o rei Africano ter encarregado Mateus de Pisano de descrever os feitos de D. João II, assim como em outro facto - o de Poliziano se oferecer para cantar os Descobrimentos portugueses em versos latinos, no Prólogo que Garcia de Resende escreveu ao seu Cancioneiro Geral, dizendo que "todos estes feitos e outros muitos doutras substâncias não são divulgados como foram, se gente doutra nação os fizera" ${ }^{35}$, já se vê a formação de conceito de importância ecuménica dos Descobrimentos portugueses.

Esta concepção teve a sua realização mais brilhante nas obras de João de Barros e em Os Lusíadas de Luís de Camôes.

Em carta ao rei D. João III, afirma Barros com alto sentimento de orgulho nacional: “... vossas armas e padróes de victorias têm tomado posse, não somente de toda a terra maritima de África e Ásia, mas ainda de outros maiores mundos, do que Alexandre lamentava, por não ter notícias deles"36. Mas a melhor prova do carácter ecuménico das Décadas é o já mencionado plano delas com as partes a chamar Europa, África e Ásia e que de qualquer maneira náo chegou a ser realizado por completo pelo próprio Barros, mas teve o seu análogo no plano de Os Lusíadas. O carácter ecuménico deste poema é tão evidente que não necessita de provas especiais. O próprio desejo de Camóes de criar uma obra ao nível de Homero e Virgílio e exceder "Rodamonte e o vẫo Rugeiro e Orlando", quer dizer, de atingir a escala de literatura mundial, corresponde à compreensão da importância universal da missão histórica da nação portuguesa. Este sentimento aparece na famosa invocação às naçôes cristâs do canto VII (“... entanto que cegos e sedentes / Andais de vosso sangue, ó gente insana, / Não faltaram cristãos atrevimentos / Nesta pequena casa Lusitana”); na conclusão do poema ("Fazei, Senhor, que nunca os admirados / Alemães, Galos, Ítalos e Ingleses / Possam dizer que são para mandados, / Mais que para mandar, os Portugueses"), e podia-se continuar esta lista dos exemplos. Mas, sem dúvida nenhuma, a maior noção da importância ecuménica dos Descobrimentos é a que se sente no episódio da Máquina do Mundo, quando Tétis e Vasco da Gama contemplam o processo de expansão marítima portuguesa no espaço cósmico.

Este sentimento de orgulho nacional náo resulta em desprezo de Zurara, Barros ou Camôes para com outras nações, e não podemos concordar com a crítica que Fidelino de Figueiredo faz a João de Barros, que, na sua opiniāo, "contemplou a história da

${ }^{33}$ Lopes, Óscar e Saraiva, José, História da Literatura Portuguesa, Porto, 1987, 14a edição, p. 290.

34 Zurara, Gomes Eanes de, Crónica do Conde D. Duarte de Meneses, Lisboa, 1978, p. 42.

35 Cancioneiro Geral de Garcia de Resende, Coimbra, 1910, Tomo I, p. 2.

36 Década Primeira da Ásia de João de Barros, Lisboa, 1628. 
conquista portuguesa do Oriente de um ponto de vista estritamente português, e por isso, não apontou o espírito íntimo, as razóes e intençóes dominantes nos processos dos índios para connosco" 37 .

Essa observação faz lembrar as críticas já mencionadas que Óscar Lopes e António José Saraiva fizeram sobre Zurara em relação ao seu "desdém por gente miúda" e "deformaçôes de perspectiva histórica".

Estas críticas ficam fora do contexto da época. Será, por exemplo, que poderíamos repreender Zurara ou Barros por náo terem usado computador no processo da sua pesquisa? Claro que na época, quando criaram as suas obras, um ponto de vista foi considerado o mais justo e o mais culto, o que não impediu os nossos autores de tratar com interesse, respeito e compaixão as outras naçóes. Sabe-se, por exemplo, que Barros usou muitas fontes orientais no seu trabalho, mas para apontar "o espírito íntimo... dos índios para connosco" seria melhor nascer índio.

Sabe-se que apesar de ser cronista oficial, patrocinado pelo próprio rei, Zurara não hesitou em levantar a sua voz contra o comércio dos escravos. "O tu celestial padre, - escreveu ele no capítulo XXV da Crónica dos Feitos da Guiné - Eu te rogo que as minhas lágrimas não sejam dano da minha consciência. E se as brutas animais com seu bestial sentir por um natural destino conhecem os danos de suas semelhantes, que queres que faça esta minha humanal natureza vendo assim ante os meus olhos aquestra miserável companhia lembrandome que são da geração dos filhos de Adão"38.

Não se pode ficar indiferente às páginas que descrevem o mercado de escravos e fazem lembrar as palavras escritas com alusão ao mesmo processo por Sá de Miranda:

"Espíritos vindos do céu,

Postos aos lanços na praça!”

João de Barros descreve com muitos pormenores a geografia, os ritos e costumes da Índia, e neste aspecto náo difere ele muito de Castanheda, porque interesse e respeito para com as outras naçóes foi um dos lugares comuns da mundividência renascentista (pode-se lembrar neste contexto Damião de Góis e o facto de que é dos Descobrimentos portugueses que resultou o mito do "bom selvagem" que se tornou tão popular durante vários séculos na Europa).

A mesma atitude para com as outras naçóes é própria de Camóes. Ele fala de "potente Samorim, mais que todos digno e grande", da "Dedálea faculdade" com que é feito o portal do templo indiano, chama a atenção dos outros povos cristáos para a situação dos "Gregos, Traces, Arménios, Georgianos". A única excepção neste aspecto faz-se para os mouros que às vezes são chamados "torpe seita" e "bárbaros e nefandos". Contudo, considerando a história da reconquista, esta atitude parece-nos mais natural do que a de alguns escritores espanhóis, entre os quais Calderón, com a sua idealização da cultura e generosidade dos árabes.

${ }^{37}$ Figueiredo, Fidelino de, História Literária de Portugal (séc. XII-XX), Rio de Janeiro, 1960 , p. 164.

${ }^{38}$ Zurara, Gomes Eanes de, Crónica dos Feitos da Guiné, Lisboa, 1978, p. 107. 
Desta maneira, uma coisa que Camões sobretudo deve a Zurara e Barros não são os factos que estes reuniram nas suas obras, mas é a sua visão da história.

Os apelos de descrever os portugueses como pessoas que vieram para a Índia "para vindimar durante três anos aquela vinha” podem parecer muito justos, mas já há muitos anos que o processo de vindima se acabou e o mundo continua a apreciar a coragem dos descobridores, porque ao lado de obras de arte e literatura, as descobertas fazem parte da contribuição positiva do Renascimento para o desenvolvimento humano e são um dos factores que formaram a civilização moderna.

A História de Castanheda, como tal, não podia servir de base para Os Lusíadas. E é muito importante assinalar que a historiografia portuguesa teve entre seus representantes pessoas de espírito tão elevado como Gomes Eanes de Zurara e o iminente humanista João de Barros.

Mas o conhecimento da História de Castanheda também enriqueceu a visão histórica do autor de Os Lusiadas.

$\mathrm{Na}$ já referida edição de Os Lusíadas organizada por Emmanuel Paulo Ramos são apontadas até as oitavas que têm como sua fonte a obra desse historiador. São as estrofes 44-46, 54, 55, 59-64, 70, 71, 84-86, 95, 98, 100, 102 e 103 do canto I; 1-8, 10-24, 25, 28, 32 do canto II; 64-108 do canto III; 10-73 do canto X. Quanto às oitavas 60-65 e 76-77 do canto IV, 4-36, 41-48, 73-85 do canto V; 5-6 do canto VI, 16-72 do canto VII, 43-46 e 59-95 do canto VIII e 1-17 do canto IX, aqui E. Paulo Ramos indica as duas fontes paralelas, que são Barros e Castanheda.

Pensamos que tudo isso é muito relativo.

É verdade que Camóes conheceu bem os factos relatados pelos cronistas portugueses, mas teve uma imaginação criadora e, quando seguia as crónicas portuguesas de perto, foi mais por motivo de sua profunda aceitação do que por impossibilidade de acrescentar alguma coisa.

Assim, por exemplo, indica o mesmo investigador A Crónica do Senhor Rei D. Afonso $V$, de Rui de Pina, como uma fonte de respectivas oitavas (canto IV, 54-60) do poema camoniano. Contudo, a comparação dos dois textos mostra que, embora Camóes pudesse aproveitar os factos relatados por Rui de Pina, a sua atitude para com ele é completamente diferente. Para Camóes o rei Africano é um soberbo vencedor de mouros que "pôde colher as maçãs de ouro, / Que somente o Tirintio colher pôde", o chefe das tropas acostumadas de cometer "maravilhas em armas, estremadas e de escritura dignas elegante”. Até o facto de D. Afonso V ter disputado a coroa de Espanha aos Reis Católicos e sacrificado o futuro da sua sobrinha D. Joana não resulta na ira de Camóes, contrariamente a Rui de Pina, que exprimiu bastante compaixão para a "Excelente Senhora", assim como para o tio do rei D. Afonso V, o famoso infante D. Pedro, cuja morte na batalha de Alfarrobeira nem sequer foi mencionada pelo poeta.

Parece que, na sua visão dos feitos de D. Afonso V, Camôes tomou em consideração mais a sua atitude para Zurara (porque o rei Africano foi, de certa maneira, um análogo português de "aquele Herói que estima e ama / Com does, mercês, favores e honra tanta / A lira Mantuana”) e vice-versa - de Zurara para com o rei.

Pode-se também lembrar um outro episódio de Os Lusíadas - o de Fernão Veloso $(\mathrm{V}, 36)$, também mencionado por ambos os cronistas, Castanheda (na versão mais abreviada) e Barros (na versão mais pormenorizada). Mas o tratamento humorístico 
do carácter do próprio Veloso e a atitude relativamente neutral (comparada com a de Barros) para com o "etíope usado", são totalmente de autoria de Camóes.

Contudo, o conhecimento da História de Castanheda contribuiu, à sua maneira, para a visão de história em Camóes. É por intermédio dele que entrou em Os Lusíadas a ideia de "verdade nua e pura", e o poeta ousou relatar as suas próprias experiências (as de contemplaçáo da tromba marítima ou do fogo de Santelmo) ao lado da descrição dos feitos heróicos dos seus compatriotas. Até as queixas de Castanheda de "trabalhos de grande fome e de muito maior sede... mil perigos... muy espantosas pelejas de bombardadas e espingardas sem conto" encontram as suas analogias em Camóes:

"Olhai que há tanto tempo que, cantando

O vosso Tejo e os vossos Lusitanos,

A Fortuna me traz peregrinando,

Novos trabalhos vendo e novos danos:

Agora o mar, agora experimentando

Os perigos Mavórcios inumanos..."

(VII, 79)

É por influência de Castanheda que entrou no poema camoniano a ideia de mostrar a prosa dos Descobrimentos, embora o material para isso nem sempre tenha procedido da História dele. Além dos mencionados episódios do canto V, fazem parte desta "prosa" os relatos sobre o escorbuto (V, 81-82), a tempestade (VI, 70-84) e todas as histórias "trágicomarítimas" contadas pelo gigante Adamastor. Um toque de impressóes pessoais (às vezes de Castanheda, às vezes do poeta ele próprio) sente-se nas referências de "cortiça cálida, cheirosa" do Ceiláo, do calambuco da Cochinchina ("Vês, corre a costa que Champa se chama, / Cuja mata é do pau cheiroso ornada"), do "fervente cume" do vulcáo na ilha Ternate, da noz-moscada das Ilhas de Banda, do "sândalo, salutífero e cheiroso" de Timor, do "cheiroso licor" (benjoim) de Samatra e em muitos outros versos de Os Lusíadas.

Também, às vezes, a voz de Castanheda "soa" nas digressões líricas de Os Lusíadas: por exemplo, as queixas de Castanheda à rainha $\mathrm{D}$. Catarina para com a ingratidão dos portugueses são muito parecidas com as palavras seguintes de Camóes:

"E ainda, Ninfas minhas, não bastava

Que tamanhas miserias me cercassem

Senão que aqueles que eu cantando andava

Tal prémio de meus versos me tornassem.

A troco dos descansos que esperava,

Das capelas de louro que me honrassem,

Trabalhos nunca usados me inventaram,

Com que em táo duro estado me deixaram!"

(VII, 81)

Também se deve comprovar que não há abismo entre Zurara e Barros, de um lado, e Castanheda de outro.

Várias ideias: a de semelhança dos feitos dos descobridores portugueses com os de heróis da Antiguidade, da importância do apoio à historiografia e à literatura de parte 
do poder real, da luta pela verdade (que, aliás, cada um deles percebia à sua própria maneira), da ingratidão dos portugueses para com seus historiadores e escritores - são próprias de todos os cronistas referidos. É interessante que ambos os rivais - Castanheda e Barros - manifestam respeito indiscutível para com Zurara.

Mas em todo o caso é importante notar que em Portugal houve cronistas que sabiam não só mostrar "as vindimas da vinha”, mas também revelar os altos sentimentos humanos: amor pela pátria e desejo de servi-la, curiosidade para com outras terras e civilizaçóes, coragem, vontade de divulgar a fé cristá, porque são sentimentos a louvar em todas as épocas da história humana.

É interessante que Camões, por sua vez, exerceu a influência não só sobre a literatura, mas também sobre a historiografia e pensamento político do seu país.

Na Década Quarta da Ásia, Diogo do Couto repete muitas histórias já consagradas pelo génio camoniano, por exemplo, a sobre a pintura dos "dinheiros por que Deus fora vendido" no escudo de Portugal, e realça os feitos de muitos descobridores já cantados pelo poeta.

Já depois do desastre em Alcácer-Quibir, Frei Amador Arrais, influenciado, como ele próprio o indicou, pelas palavras do Velho do Restelo, lamenta de os portugueses não se terem "agasalhado" na África.

O problema do uso de material histórico na literatura de ficção surgiu em todas as literaturas desenvolvidas, não sendo estranho à literatura russa.

O fundador da literatura clássica russa, Alexandre Puchkine, interessou-se muito pela figura do dirigente da insurreição popular contra o regime de Catarina II, Iemelian Pugatchov. Em 1834, ele publicou a investigação histórica deste acontecimento chamada $A$ história da insurreição de Pugatchov acompanhada pelos documentos da época. Em 1836, publicou um conto, quer dizer, uma obra de literatura de ficção sobre os mesmos acontecimentos - A filhinha do capitão. A comparação da imagem de Pugatchov em ambas foi feita pela grande poetisa russa do século XX Marina Tsvetáieva no seu ensaio Puchkine e Pugatchov (1937). Ela reparou que na História da insurreição de Pugatchov, de acordo com as fontes documentais, Pugatchov é representado como homem extremamente cruel que cometeu numerosas atrocidades, muitas vezes contra pessoas completamente inocentes. Ela lembra o episódio quando levaram a Pugatchov o comandante de uma fortaleza, senhor Kharlov, cujo olho, tirado fora por uma lança, ficou pendurado sobre a sua bochecha. Pugatchov mandou executá-lo, a ele a à esposa, fez da filha deles a sua concubina, mas passados uns dias mandou assassiná-la a ela e ao seu irmão, um miúdo de sete anos de idade.

De um chefe de outra fortaleza, os insurrectos tiraram a pele enquanto ele ainda estava vivo, e, como era gordo, usaram a sua gordura para tratar as feridas deles próprios.

Mas Puchkine sabia perfeitamente que a opinião popular criou uma imagem de Pugatchov como a de uma figura simpática, defensor dos pobres e o czar do campesinato. O escritor percebeu perfeitamente que a criação do brilhante império nos tempos de Catarina II custou muito ao povo russo, sobretudo aos camponeses-servos, e sentiu a grande compaixão pelo espírito de protesto popular, embora percebesse a inevitabilidade da derrota do levantamento referido. Em Filhinha do capitão ele fala em atrocidades de Pugatchov, mas em geral, sem mencionar pormenores. Contudo o czar popular é apresentado nesta sua obra como uma pessoa magnânima, bondosa, fiel em amizade 
e dedicada à ideia de felicidade popular. Não dispondo das possibilidades de justificar esta imagem por meios documentais, Puchkine usa os vários meios artísticos, entre os quais o seguinte: Pugatchov conta uma fábula sobre o corvo que vive trezentos anos, porque come coisas mortas, e a águia que vive apenas trinta e três anos e bebe "o sangue vivo". Desejando prolongar a sua vida, a águia tentou provar "a carne morta", mas não conseguiu engoli-la e disse: "Não, irmão corvo. Antes quero beber uma vez sangue vivo do que comer durante trezentos anos carne morta, e depois seja o que Deus quiser".

Lendo esta fábula que mostra o carácter combativo e orgulhoso do chefe popular, pode-se lembrar o Prólogo da Década Terceira de João de Barros onde se diz: "Tem tanto poder a força da eloquência, que mais doce e aceita é na orelha e no ânimo ũa fabula composta com o decoro que lhe convém, que ũa verdade sem ordem e sem ornato, que é a forma natural dela".

No caso de Puchkine, "a fábula composta" exprimiu melhor o conteúdo objectivo do levantamento popular do que a verdade histórica. Pode-se lembrar um outro escritor russo Leo Tolstoi, que no seu romance Guerra e Paz apresentou Kutuzov como uma pessoa que resolveu não fazer nada, deixando o processo de guerra contra Napoleão à sua ordem natural e ao povo russo. As fontes históricas mostram que Kutuzov, pelo contrário, era pessoa activa e as suas operaçóes militares foram sempre muito bem pensadas. Mas Leo Tolstoi, que aliás também estudou centenas de documentos da época, melhor que os outros historiadores percebeu que a causa principal da vitória da Rússia sobre Napoleão foi a participação activa de todo o povo russo na luta pela independência nacional, e não o génio militar dos seus generais.

Para concluir este meu estudo, devo dizer que os grandes escritores têm sempre uma consciência de que estão a trabalhar para a eternidade, e por isso náo ficam no cativeiro da verdade dos factos, embora tenham todo o respeito para com ela. A visão dos Descobrimentos portugueses em Os Lusíadas de Luís de Camôes criou-se à base da fusão da informação contida nos documentos históricos, das impressões pessoais do poeta ele próprio, da comparação de pontos de vista de vários historiadores portugueses, de avaliaçôes profundas sobre toda a história do seu país e da história mundial. Também contribuiu para isso o conhecimento profundo, por Camóes, da psicologia nacional e o seu ideário renascentista com uma certa tendência para idealização do homem. As grandes obras da literatura, por um lado, baseiam-se sempre sobre uma tradição, mas por outro lado, possuem o carácter inovador e estão a criar novas tradiçóes. No caso de Camóes, foi muito importante já terem existido em Portugal as obras de historiógrafos como Gomes Eanes de Zurara e João de Barros, assim como de escritores como António Ferreira e Garcia de Resende que em grande parte determinaram a sua visão dos Descobrimentos que, apesar de todas as críticas possíveis, entrou, através de Os Lusiadas, na literatura mundial e fez a sua parte indispensável e de incomparável valor. 